\title{
Biological Indices of Groundnut (Arachis hypogaea L.) + Sweet Corn (Zea mays var. Saccharata) Intercropping System
}

\author{
J. G. Hadiyal", R. K. Mathukia, K. B. Parmar and N. N. Damor \\ Department of Agronomy, College of Agriculture, Junagadh Agricultural University, \\ Junagadh-362 001, Gujarat, India \\ *Corresponding author
}

\begin{abstract}
A B S T R A C T
Keywords

Groundnut, Arachis hypogaea L., Sweet corn, Zea mays var. saccharata, Groundnut equivalent yield (GEY), Land equivalent ratio (LER), Land equivalent coefficient (LEC) and Area time equivalent ratio (ATER)

Article Info

Accepted:

17 August 2020 Available Online: 10 September 2020

An experiment was conducted during kharif seasons of year 2018-19 and 2019-20 on medium black calcareous clayey soil at Junagadh (Gujarat) to study crop intensification and diversification through groundnut (Arachis hypogaea L.) + sweet corn (Zea mays var. saccharata) intercropping system. The groundnut (cv. GG-20) was mix/intercropped with sweet corn (cv. Sugar-75) and pigeonpea (cv. GJP-1). Ten treatments comprising mix/intercropping systems viz., sole groundnut, sole sweet corn, sole pigeonpea, groundnut + sweet corn in 1:1, 2:1 and 3:1 row ratio in replacement series, groundnut + sweet corn $(3: 1$ in additive series), groundnut + sweet corn with paired row $(45-75-45 \mathrm{~cm})(2: 1$ in additive series), mix cropping of groundnut $80 \%+$ sweet corn $20 \%$ and groundnut + pigeonpea (3:1 in replacement series) were evaluated in randomized block design with three replications. The productivity of these systems in terms of groundnut pod equivalent yield was significantly higher $(2338 \mathrm{~kg} / \mathrm{ha})$ with intercropping of groundnut + sweet corn with paired row $(45-75-45 \mathrm{~cm})(2: 1$ in additive series) followed by intercropping of groundnut + sweet corn (3:1 in additive series) (2156 $\mathrm{kg} / \mathrm{ha}$ ) than sole groundnut $(1658 \mathrm{~kg} / \mathrm{ha})$ and other mix/intercropping systems. The biological efficiency of the mix/intercropping systems in terms of the LER (1.537), LEC (0.545) and ATER (1.414) were also recorded significantly higher under intercropping of groundnut + sweet corn with paired row $(45-75-45 \mathrm{~cm})$ ( $2: 1$ in additive series).
\end{abstract}

\section{Introduction}

India is one of the leading oilseed producing countries in the world. Oilseeds form the second largest agricultural commodity after cereals. Groundnut is an important oilseed crop has been the backbone of agriculture economy of India from time immemorial.
Crop has its own importance due to high edible oil content and nutritional value of kernel as human feed and haulm as rich feed for cattle.

In Gujarat, the region of Saurashtra considered as the groundnut oil bowl of the country. The average area under kharif 
groundnut cultivation in Gujarat during 201718 stood at 16.27 lakh hectares with production of 39.70 lakh tonnes with productivity of $2440 \mathrm{~kg} / \mathrm{ha}$ (DOA, 2018). The average area under groundnut cultivation in Junagadh district during 2017-18 was 2.58 lakh hectares with production of 3.52 lakh tonnes with productivity of $1363 \mathrm{~kg} / \mathrm{ha}$ (DOA, 2018).

Keeping in view the numerous problems that the agriculture is facing today and urgent need to enhance crop productivity to ensure food security for all the people there is need to promote sustainable crop intensification likes mixed cropping and intercropping. In mixed cropping, two or more crops grown simultaneously on the same pieces of land in mixer, while in intercropping system two or more crops are grown simultaneously on the same area in a definite row pattern.

Intercropping is an age old practice in India, especially under rainfed conditions, which aims to increase total productivity per unit area and to equitably and judiciously utilize land resources and farming inputs including labour (Mohapatra et al., 2013). Main objective of intercropping is now more towards augmenting the total productivity per unit area of the land per unit time by growing more than one crop in the same field, the prime objective being better utilization of environmental resources (Khokhar et al., 2004). Intercropping system is mostly adopted in rainfed condition, which acts mainly as risk cover against crop failures due to vagaries of monsoon, pest attack and uneven distribution of rainfall. Development of feasible and economically viable intercropping systems largely depends on selection of compatible crops, planting time and adoption of proper planting geometry (Kumar et al., 2013). The suitable intercropping systems might increase the total production through efficient utilization of production factors like space, water, nutrient etc. and stability of crop yield in rainfed conditions can be achieved with crop substitution and intercropping (Knudsen et al., 2004).

Groundnut is the pre-dominant kharif crop of the Saurashtra region. Yield fluctuation under vagaries of monsoon, disease-pest and low market price are the major constraints in groundnut cultivation. Hence, during last few years most of the farmers switched over to Bt cotton cultivation. But further disease-pest problem and low market price of Btcotton is now become the major constraint besides some production problems. Animal husbandry is an important and integral component of farming system in the Saurashtra region. The dominance of groundnut over the years is mainly ascribed to the haulm of groundnut, which serves as valuable fodder. This situation necessitates crop diversification, which should be remunerative and also provide fodder. As legume + cereal mixture is an ideal intercropping system, sweet corn can suitably be intercropped with groundnut. Sweet corn has big market potential. In addition, green fodder derived after harvest is an additional advantage of sweet corn.

Speciality corns viz., sweet corn, pop corn, baby corn, etc. assume tremendous market potential not only in India but also in the international market. These speciality corns with their high market value are perfectly suitable to peri-urban agriculture. Thus, they promise higher income to maize growers. Out of the various speciality corns, sweet corn (Zea mays L. var. saccharata Sturt) has a big market potential. It is a hybridized variety of maize specifically bred to increase the sugar content. It is one of the most popular vegetables in countries like USA and Canada and is becoming increasingly popular in India and other Asian countries also. It is consumed in the immature stage of the cob. The kernels 
of sweet corn taste much sweeter than normal corn especially at 18 to 21 days after pollination. In addition, fodders derived after harvest may be fed to animals or sold, which bring additional income to the farmers.

\section{Materials and Methods}

The field experiment was conducted in kharif seasons of year 2018-19 and 2019-20 at Instructional farm, Department of Agronomy, College of Agriculture, Junagadh Agricultural University, Junagadh. The experiment was conducted on medium black clayey textured soil, which was medium in organic carbon (0.69 and $0.65 \%$ in 2018-19 and 2019-20, respectively), slightly alkaline in reaction with pH (8.01 and 7.98 in 2018-19 and 201920 , respectively) and EC ( 0.48 and $0.53 \mathrm{dS} / \mathrm{m}$ in 2018-19 and 2019-20, respectively). The soil was medium in available nitrogen (251.30 and $257.18 \mathrm{~kg} / \mathrm{ha}$ in 2018-19 and 2019-20, respectively), medium in available phosphorus (38.14 and $36.57 \mathrm{~kg} / \mathrm{ha}$ in 2018 19 and 2019-20, respectively) and medium in available potash (268.20 and $274 \mathrm{~kg} / \mathrm{ha}$ in 2018-19 and 2019-20, respectively).

The mean maximum and minimum temperature during the crop growth and development period in 2018-19 ranged between 27.0 to $37.9^{\circ} \mathrm{C}$ and 11.0 to $26.6^{\circ} \mathrm{C}$, respectively. The range of rainfall was 1.8 $447.8 \mathrm{~mm}$ (Highest in second week of July and third week of July) with seasonal rainfall of $790.6 \mathrm{~mm}$. The rain commenced from $17^{\text {th }}$ June at normal onset of monsoon and withdrew from $21^{\text {th }}$ September during the year 2018-19. The range of average relative humidity, wind speed, bright sun shine and daily evaporation was $41.5-95.5 \%, 0.1-9.9$ $\mathrm{km} / \mathrm{h}, 2.4-13.0 \mathrm{~h}$ and $0.2-5.9 \mathrm{~mm}$, respectively during the year 2018-19.

While in year 2019-20, the mean maximum and minimum temperature during the crop growth and development period in 2019-20 ranged between 25.4 to $35.6^{\circ} \mathrm{C}$ and 9.7 to $27.5^{\circ} \mathrm{C}$, respectively. The range of rainfall was $0.5-248.0 \mathrm{~mm}$ (Highest in first week of September and last week of July) with seasonal rainfall of $1492.2 \mathrm{~mm}$. The rain commenced from $14^{\text {th }}$ June at normal onset of monsoon and extended upto $6^{\text {th }}$ October during the year 2019-20. The range of average relative humidity, wind speed, bright sun shine and daily evaporation was 44.0$94.5 \%, 2.2-14.6 \mathrm{~km} / \mathrm{h}, 0.7-9.0 \mathrm{~h}$ and $1.6-7.1$ $\mathrm{mm}$, respectively during the year 2019-20.

Ten treatments comprising mix/intercropping systems viz., sole groundnut with spacing 60 $\mathrm{cm} \times 10 \mathrm{~cm}\left(\mathrm{~T}_{1}\right)$, sole sweet corn with spacing $60 \mathrm{~cm} \times 20 \mathrm{~cm}\left(\mathrm{~T}_{2}\right)$, sole pigeonpea with spacing $90 \mathrm{~cm}$ x $20 \mathrm{~cm}\left(\mathrm{~T}_{3}\right)$, groundnut + sweet corn 1:1 in replacement series $\left(\mathrm{T}_{4}\right)$, groundnut + sweet corn 2:1 in replacement series $\left(\mathrm{T}_{5}\right)$, groundnut + sweet corn $3: 1$ in replacement series $\left(\mathrm{T}_{6}\right)$, groundnut + sweet corn 3:1 in additive series $\left(\mathrm{T}_{7}\right)$, groundnut + sweet corn with paired row $(45-75-45 \mathrm{~cm}) 2: 1$ in additive series $\left(\mathrm{T}_{8}\right)$, mix cropping of groundnut $80 \%+$ sweet corn $20 \%\left(\mathrm{~T}_{9}\right)$ and groundnut + pigeonpea $3: 1$ in replacement series $\left(\mathrm{T}_{10}\right)$ were evaluated in randomized block design replicated thrice with gross plot size of $5.0 \mathrm{~m} \times 7.20 \mathrm{~m}$ and net plot size of 4.0 $\mathrm{m} \times 5.40 \mathrm{~m}$ for $\mathrm{T}_{3} \& \mathrm{~T}_{5}$ and $4.0 \mathrm{~m} \times 4.80 \mathrm{~m}$ for $\mathrm{T}_{1}, \mathrm{~T}_{2}, \mathrm{~T}_{4}, \mathrm{~T}_{6}, \mathrm{~T}_{7}, \mathrm{~T}_{8}, \mathrm{~T}_{9} \& \mathrm{~T}_{10}$. The groundnut (cv. GG-20) was intercropped with sweet corn (cv. Sugar-75) and pigeonpea (cv. GJP-1) were raised with standard package of practices.

The entire recommended doses of fertilizer for groundnut and pigeonpea as per sole and intercrops on the basis of area occupied were applied as basal application in the form of urea, diammonium phosphate and muriate of potash. While, the half dose of nitrogen and entire dose of phosphorus and potassium for sweet corn as per sole and intercrops on the 
basis of area occupied were applied as basal application in the form of urea, diammonium phosphate and muriate of potash at just before sowing in the furrows. Remaining half dose of nitrogen was top-dressed as urea at 30 DAS.

The seeds of groundnut, sweet corn and pigeonpea were sown by dibbling in fertilized furrows and covered with the soil. Gap filling was done after establishment and the seedlings were thinned at 15 DAS to maintain required plant population. Plant protection practices were adopted to as when required. All other agronomic practices were followed as per recommended package of practices. Both sole and intercrops were harvested manually at their physiological maturity. The sun dried crops were threshed manually. Observations on relevant parameters of all the crops were recorded by following the standard procedures.

The biological indices of mix/intercropping systems were determined in terms of the groundnut equivalent yield (GEY), land equivalent ratio (LER), land equivalent coefficient (LEC) and area time equivalent ratio (ATER). All the data were subjected to statistical analysis by adopting appropriate analysis of variance. Wherever the $\mathrm{F}$ values found significant at 5\% level of probability, the critical difference (CD) values were computed for making comparison among the treatment means as described by Panse and Sukhatme (1985).

\section{Groundnut Equivalent Yield (GEY)}

The groundnut equivalent yield of intercropping systems was calculated by taking into account the yield of component crops and prevailing market price of both main crop and intercrops. The GEY of intercropping systems was calculated by using the following formula.

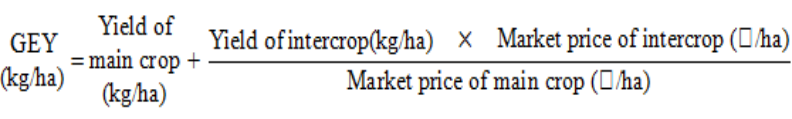

\section{Land Equivalent Ratio (LER)}

Land equivalent ratio is defined as the relative land area under sole crop that is required to produce the yield obtained in intercropping system. LER was used criterion for measuring efficiency of intercropping advantage using the resources of environment compared with monocropping. When the value of LER is $>1$, intercropping favours the growth and yield of the species. By contrast, when LER $<1$, intercropping negatively affects the growth and yield of the plants grown in mixtures. The LER was worked out by the following formula suggested by Mead and Willey (1980).

$\mathrm{LER}=\mathrm{LA}+\mathrm{LB}=\frac{\mathrm{YA}}{\mathrm{SB}}+\frac{\mathrm{YB}}{\mathrm{SB}}$

Where,

LA and LB are the LER for individual crops.

$\mathrm{YA}$ and $\mathrm{YB}$ are the individual crop yield in intercropping.

SA and SB are their sole crop yields.

\section{Land Equivalent Coefficient (LEC)}

Land equivalent coefficient (LEC) was calculated by using the following formula suggested by Adetiloye et al., (1983).

\section{$\mathrm{LEC}=\mathrm{LA} \times \mathrm{LB}$}

Where,

LA $=$ LER of main crop

$\mathrm{LA}=\mathrm{LER}$ of intercrop 


\section{Area Time Equivalent Ratio (ATER)}

Area time equivalent ratio (ATER) provides more realistic comparison of the yield advantage of intercropping over monocropping in terms of time taken by component crops in the intercropping systems. ATER was calculated by using the following formula suggested by Hiebsch and McCollum (1987).

ATER $=\frac{(\mathrm{LA} \times \mathrm{TA})+(\mathrm{LB} \times \mathrm{TB})}{\mathrm{T}}$

Where,

LA and LB $=$ Partial LER of crop A and B
$\mathrm{TA}$ and $\mathrm{TB}=$ Duration (days) of crop A and $\mathrm{B}$ $\mathrm{T}=$ Duration (days) of the intercropping system

\section{Results and Discussion}

The results indicated that different mix/intercropping systems exhibited their significant influence on groundnut equivalent yield (Table 1). Significantly the maximum groundnut pod equivalent yield was obtained under intercropping of groundnut + sweet corn with paired row $(45-75-45 \mathrm{~cm}) 2: 1$ in additive series $\left(\mathrm{T}_{8}\right)$, which stayed statistically at par with groundnut + sweet corn $(3: 1)$ in additive series $\left(\mathrm{T}_{7}\right)$.

Table.1 Groundnut pod equivalent yield and land equivalent ratio as influenced by groundnut based mix/intercropping systems

\begin{tabular}{|c|c|c|c|c|c|c|c|}
\hline \multirow{2}{*}{\multicolumn{2}{|c|}{ Treatment }} & \multicolumn{3}{|c|}{$\begin{array}{l}\text { Groundnut pod equivalent yield } \\
\text { (kg/ha) }\end{array}$} & \multicolumn{3}{|c|}{ Land equivalent ratio } \\
\hline & & 2018-19 & 2019-20 & Pooled & 2018-19 & 2019-20 & Pooled \\
\hline $\mathbf{T}_{1}$ & Sole groundnut $(60 \mathrm{~cm} \times 10 \mathrm{~cm})$ & 1615 & 1701 & 1658 & 1.000 & 1.000 & 1.000 \\
\hline $\mathbf{T}_{2}$ & Sole sweet corn $(60 \mathrm{~cm} \times 20 \mathrm{~cm})$ & 1519 & 1309 & 1414 & 1.000 & 1.000 & 1.000 \\
\hline $\mathbf{T}_{3}$ & Sole pigeonpea $(90 \mathrm{~cm} \times 20 \mathrm{~cm})$ & 1660 & 1718 & 1689 & 1.000 & 1.000 & 1.000 \\
\hline $\mathbf{T}_{4}$ & $\begin{array}{l}\text { Groundnut + Sweet corn }(1: 1 \\
\text { Replacement series })\end{array}$ & 1382 & 1282 & 1332 & 0.987 & 0.998 & 0.994 \\
\hline $\mathbf{T}_{5}$ & $\begin{array}{l}\text { Groundnut + Sweet corn }(2: 1 \\
\text { Replacement series })\end{array}$ & 1679 & 1616 & 1648 & 1.033 & 1.012 & 1.022 \\
\hline $\mathbf{T}_{6}$ & $\begin{array}{l}\text { Groundnut + Sweet corn }(3: 1 \\
\text { Replacement series })\end{array}$ & 1822 & 1849 & 1836 & 1.065 & 1.055 & 1.060 \\
\hline $\mathbf{T}_{7}$ & $\begin{array}{l}\text { Groundnut }+ \text { Sweet corn (3:1 Additive } \\
\text { series) }\end{array}$ & 2158 & 2153 & 2156 & 1.303 & 1.296 & 1.299 \\
\hline $\mathbf{T}_{8}$ & $\begin{array}{l}\text { Groundnut }+ \text { Sweet corn with paired row } \\
(45-75-45 \mathrm{~cm})(2: 1 \text { Additive series })\end{array}$ & 2364 & 2311 & 2338 & 1.532 & 1.543 & 1.537 \\
\hline $\mathbf{T}_{9}$ & $\begin{array}{l}\text { Mix cropping (Groundnut } 80 \%+\text { Sweet } \\
\text { corn } 20 \% \text { ) }\end{array}$ & 1755 & 1820 & 1788 & 1.132 & 1.154 & 1.143 \\
\hline \multirow[t]{10}{*}{$T_{10}$} & $\begin{array}{l}\text { Groundnut + Pigeonpea ( } 3: 1 \\
\text { Replacement series) }\end{array}$ & 1761 & 1909 & 1835 & 1.133 & 1.172 & 1.153 \\
\hline & S.Em. \pm & 84 & 129 & 77 & 0.049 & 0.040 & 0.031 \\
\hline & C.D. at $5 \%$ & 250 & 385 & 221 & 0.145 & 0.118 & 0.090 \\
\hline & C.V. \% & 8.23 & 12.71 & 10.70 & 7.53 & 6.14 & 6.87 \\
\hline & Year & & & & & & \\
\hline & S.Em. \pm & & & 34 & & & 0.014 \\
\hline & C.D. at $5 \%$ & & & NS & & & NS \\
\hline & $\mathbf{Y} \times \mathbf{T}$ & & & & & & \\
\hline & S.Em. \pm & & & 109 & & & 0.044 \\
\hline & C.D. at $5 \%$ & & & NS & & & NS \\
\hline
\end{tabular}


Table.2 Land equivalent coefficient and area time equivalent ratio as influenced by groundnut based mix/intercropping systems

\begin{tabular}{|c|c|c|c|c|c|c|c|}
\hline \multirow{2}{*}{\multicolumn{2}{|c|}{ Treatment }} & \multicolumn{3}{|c|}{ Land equivalent coefficient } & \multicolumn{3}{|c|}{ Area time equivalent ratio } \\
\hline & & 2018-19 & 2019-20 & Pooled & 2018-19 & 2019-20 & Pooled \\
\hline $\mathbf{T}_{1}$ & Sole groundnut $(60 \mathrm{~cm} \times 10 \mathrm{~cm})$ & 1.000 & 1.000 & 1.000 & 1.000 & 1.000 & 1.000 \\
\hline $\mathbf{T}_{2}$ & Sole sweet corn $(60 \mathrm{~cm} \times 20 \mathrm{~cm})$ & 1.000 & 1.000 & 1.000 & 1.000 & 1.000 & 1.000 \\
\hline $\mathbf{T}_{3}$ & Sole pigeonpea $(90 \mathrm{~cm} \times 20 \mathrm{~cm})$ & 1.000 & 1.000 & 1.000 & 1.000 & 1.000 & 1.000 \\
\hline $\mathbf{T}_{4}$ & $\begin{array}{l}\text { Groundnut + Sweet corn }(1: 1 \\
\text { Replacement series })\end{array}$ & 0.237 & 0.242 & 0.240 & 0.865 & 0.877 & 0.871 \\
\hline $\mathbf{T}_{5}$ & $\begin{array}{l}\text { Groundnut + Sweet corn }(2: 1 \\
\text { Replacement series })\end{array}$ & 0.248 & 0.221 & 0.235 & 0.950 & 0.938 & 0.944 \\
\hline $\mathbf{T}_{6}$ & $\begin{array}{l}\text { Groundnut + Sweet corn }(3: 1 \\
\text { Replacement series })\end{array}$ & 0.238 & 0.196 & 0.217 & 0.997 & 0.998 & 0.997 \\
\hline $\mathbf{T}_{7}$ & $\begin{array}{l}\text { Groundnut + Sweet corn (3:1 Additive } \\
\text { series) }\end{array}$ & 0.342 & 0.313 & 0.328 & 1.224 & 1.221 & 1.222 \\
\hline $\mathbf{T}_{8}$ & $\begin{array}{l}\text { Groundnut }+ \text { Sweet corn with paired row } \\
(45-75-45 \mathrm{~cm})(2: 1 \text { Additive series })\end{array}$ & 0.550 & 0.540 & 0.545 & 1.410 & 1.418 & 1.414 \\
\hline $\mathbf{T}_{9}$ & $\begin{array}{l}\text { Mix cropping (Groundnut } 80 \%+\text { Sweet } \\
\text { corn } 20 \% \text { ) }\end{array}$ & 0.231 & 0.211 & 0.221 & 1.075 & 1.101 & 1.088 \\
\hline $\mathbf{T}_{10}$ & $\begin{array}{l}\text { Groundnut + Pigeonpea (3:1Replacement } \\
\text { series) }\end{array}$ & 0.276 & 0.303 & 0.290 & 0.867 & 0.878 & 0.872 \\
\hline & S.Em. \pm & 0.029 & 0.028 & 0.020 & 0.047 & 0.034 & 0.029 \\
\hline & C.D. at $5 \%$ & 0.087 & 0.085 & 0.059 & 0.138 & 0.100 & 0.082 \\
\hline & C.V. $\%$ & 9.89 & 9.81 & 9.85 & 7.76 & 5.61 & 6.76 \\
\hline & Year & & & & & & \\
\hline & S.Em. \pm & & & 0.009 & & & 0.013 \\
\hline & C.D. at $5 \%$ & & & NS & & & NS \\
\hline & $Y \times T$ & & & & & & \\
\hline & S.Em. \pm & & & 0.029 & & & 0.041 \\
\hline & C.D. at $5 \%$ & & & NS & & & NS \\
\hline
\end{tabular}

However, significantly the minimum groundnut pod equivalent yield was obtained under groundnut + sweet corn 1:1 in replacement series $\left(\mathrm{T}_{4}\right)$. But intercropping of groundnut + sweet corn $(3: 1$ in replacement series), groundnut + pigeonpea $3: 1$ in replacement series and mix cropping of groundnut $80 \%+$ sweet corn $20 \%$ recorded higher groundnut equivalent yield as compared to sole cropping. This might be due to better utilization of different resources in these mix/intercropping systems.

Land equivalent ratio of mix/intercropping systems were computed and presented in Table 1. Significantly the highest value of mean land equivalent ratio (1.537) was obtained under intercropping of groundnut + sweet corn with paired row $(45-75-45 \mathrm{~cm}) 2: 1$ in additive series $\left(\mathrm{T}_{8}\right)$ over other mix/intercropping systems. This result indicated that $53.7 \%$ greater area would be required by a sole cropping system to recover the yield of intercropping system. The mean land equivalent ratio in two years ranged from 1.022 to 1.537 , indicating biological sustainability of mix/intercropping systems over sole cropping. All the mix/intercropping systems had higher LER than 1 (Except groundnut + sweet corn 1:1 in replacement series), which shows mix/intercropping systems advantage. The advantage accrued from intercropping systems, as evident from competitive functions, is due to better utilization of all resources under mixtures. 
Land equivalent coefficient was significantly influenced by different mix/intercropping systems (Table 2). Among the mix/intercropping systems, significantly the highest value of land equivalent coefficient $(0.550, \quad 0.540$ and 0.545$)$ noted under intercropping of groundnut + sweet corn with paired row (45-75-45 cm) 2:1 in additive series $\left(T_{8}\right)$ during the both years and in pooled results. Land equivalent coefficient was greater than 0.25 under intercropping of groundnut + sweet corn 3:1 in additive series and groundnut + pigeonpea 3:1 in replacement series, which indicated that sweet corn and pigeonpea can grow in mixture with groundnut under these intercropping system without major adverse effects.

Area time equivalent ratio provides more a realistic comparison of the yield advantage of intercropping over that of sole cropping than LER as it considers variation in time taken by the component crops of different mix/intercropping systems. Among the mix/intercropping systems, significantly the highest value of area time equivalent ratio $(1.410,1.418$ and 1.414) was recorded under intercropping of groundnut + sweet corn with paired row (45-75-45 cm) 2:1 in additive series $\left(T_{8}\right)$ during the both years and in pooled results (Table 2). Area time equivalent ratio was greater than one under intercropping of groundnut + sweet corn 3:1 in additive series and mix cropping of groundnut $80 \%+$ sweet corn $20 \%$ shows mix/intercropping systems advantage. In contrast, area time equivalent ratio was less than one, which indicate poor utility of all resources under intercropping system.

The highest amount of groundnut equivalent yield (GEY), land equivalent ratio (LER), land equivalent coefficient (LEC) and area time equivalent ratio (ATER) were recorded under intercropping of groundnut + sweet corn with paired row (45-75-45 cm) 2:1 in additive series.
These findings are in vicinity of those reported by Alom et al., (2009), Sutharsan and Srikrishnah (2015) and Amanullah (2017).

\section{References}

Adetiloye, P. O.; Ezedinma, F. O. C. and Okigho, B. N. 1983. A land equivalent coefficient concept for the evaluation of competitive and productive interactions on simple complex mixtures. Ecological Modeling, 19: 27-39.

Alom, M. S.; Paul, N. K. and Quayyum, M. A. 2009. Performances of different hybrid maize (Zea mays L.) varieties under intercropping system with groundnut (Arachis hypogaea L.). Bangladesh Journal of Agricultural Research, 34(4): 585-595.

Amanullah, J. A. 2017. Intercropping and rows configuration influence productivity of dryland groundnut (Arachis hypogea L.). Discovery, 53(254): 92-99.

DOA. 2018. District-wise Area, Production and Yield of Important Food and NonFood Crops Year 2017-18. Directorate of Agriculture, Gujarat state, Gandhinagar. Available at http://www.dag.gujarat.gov.in > accessed 3 December, 2019.

Hiebsch, C. K. and McCollum, R. E. 1987. Area time equivalent ratio, a method for evaluating productivity of intercrops. Journal of Agronomy, 79: 15-22.

Khokhar, A. K.; Porwal, M. K. and Meena, O. P. 2004. Production potential and economic feasibility of soybean (Glycine max L.) + maize (Zea mays L.) intercropping system at different spatial arrangement and fertility levels. Journal of Eco-Physiology, 7(1): 61-64.

Knudsen, M. T.; Hauggaard, N. H., Jornsdard, B. and Jensen, E. S. 2004. Comparison of interspecific completion and $\mathrm{N}$ use in 
pea-barley, fababean-barley and lupinbarley intercrops grown at two temperate locations. European Journal of Agronomy, 142: 617-627.

Kumar, P.; Rana, K. S.; Ansari, M. A. and Om, H. 2013. Effect of planting system and phosphorus on productivity, moisture use efficiency and economics of sole and intercropped pigeonpea (Cajanus cajan) under rainfed condition of northern India. Indian Journal of Agricultural Science, 83:549-554.

Mead, R. and Willey, R. W. 1980. The concept of land equivalent ratio and advantages in yields for intercropping. Experimental Agriculture, 16: 217-228.

Mohapatra, A. K.; Mishra, P. J. and Das, L. K. 2013. Fertilizer requirement in ragi
(Eleusine coracana) + soybean (Glycine $\max$ L.) intercropping system under rainfed condition. Annals of Agricultural Research,22(3):323-328.

Panse, V. G. and Sukhatme, P. V. 1985. Statistical Methods for Agricultural Workers. Indian Council of Agricultural Research, New Delhi, pp. 97-123.

Sutharsan, S. and Srikrishnah, S. 2015. Effect of different spatial arrangements on the growth and yield of maize (Zea mays L.) and groundnut (Arachis hypogaea L.) intercrop in the sandy regosol of Eastern region of Sri Lanka. Research Journal of Agriculture and Forestry Sciences, 3(2): 16-19.

\section{How to cite this article:}

Hadiyal, J. G., R. K. Mathukia, K. B. Parmar and Damor, N. N. 2020. Biological Indices of Groundnut (Arachis hypogaea L.) + Sweet Corn (Zea mays var. Saccharata) Intercropping System. Int.J.Curr.Microbiol.App.Sci. 9(09): 2236-2243. doi: https://doi.org/10.20546/ijcmas.2020.909.278 